\title{
Augmented Cell Signaling by Betanin insights Cancer Cell Remodeling: A Molecular Docking and Experimental
}

\section{Approach}

\author{
Rajkuberan Chandrasekaran 1(D), Sangilimuthu Alagar Yadav 1(D), Rajiv Periakaruppan 1(D), \\ Seetharaman Prabukumar $^{2}$ (D), Mosleh Mohammad Abomughaid ${ }^{3}$ (D), Noura Al-Dayan ${ }^{4}$ (D), \\ Yara Al-Digi ${ }^{5}$, Sugapriya Dhanasekaran 6,* (D)
}

1 Department of Biotechnology, Karpagam Academy of Higher Education, Coimbatore, India; kuberan87@gmail.com (R.C.), prabukmr89@gmail.com (S.A.Y.), rajivsmart15@gmail.com (R.P.);

2 Department of Biotechnology, Bharathidasan University, Tiruchirappalli, India; prabukmr89@ gmail.com (S.P.);

3 Department of Medical Laboratory Sciences, College of Applied Medical Sciences, University of Bisha, Kingdom of Saudi Arabia; moslehali@ub.edu.sa (M.M.A.);

4 Department of Medical Lab Sciences, College of Applied Medical Sciences, Prince Sattam Bin Abdulaziz University, Al Kharj, Kingdom of Saudi Arabia; n.aldayan@psau.edu.sa (N.A.D);

5 College of Medicine, King Saud University, Riyadh, Kingdom of Saudi Arabia; yara.aldeaji@gmail.com (Y.A.D.);

6 Department of Medical Lab Sciences, College of Applied Medical Sciences, Prince Sattam Bin Abdulaziz University, Wadi Ad Dawasir Campus, Kingdom of Saudi Arabia; sughaphd@yahoo.com (S.D.);

* Correspondence: sughaphd@yahoo.com (S.D.);

Received: 16.05.2021; Revised: 25.06.2021; Accepted: 2.07.2021; Published: 8.08.2021

\begin{abstract}
Molecular docking analysis has shown to be an important tool for systematically harnessing natural pigment betanin's structural diversity. Natural betanin pigment was used to investigate its anticancer efficacy by in vitro cytotoxicity and cell cycle analysis in A549 lung cancer cell line. Furthermore, docking analysis was used to determine the promising molecular targets for the betanin using different receptor proteins and enzymes responsible for DNA replication (DNA topoisomerases I and II), cell cycle (CDK-6), and in silico apoptotic markers (Bcl-2 and caspase-3) using Glide Schrodinger. In vitro analysis revealed that betanin exerts cytotoxic effects in a cancer cell by inducing apoptosis in a dose-dependent manner with an $\mathrm{IC}_{50}$ value of $17 \mu \mathrm{M}$. Furthermore, the cell cycle arrest in response to betanin treatment was strongly observed in flow cytometry analysis. The in silico docking results revealed that betanin exhibited splendid interaction with high affinity against the CDK-6, Bcl2, and caspase-3 with superior docking scores. Betanin was best docked with DNA topoisomerase II than DNA topoisomerase I. Overall, our report provides scientific evidence that betanin is a novel drug moiety with anticancer property attributes that might be developed and formulated as drug candidate/lead compounds for cancer chemotherapy.
\end{abstract}

Keywords: betanin; lung cancer; apoptosis; molecular docking; cytotoxicity.

(C) 2021 by the authors. This article is an open-access article distributed under the terms and conditions of the Creative Commons Attribution (CC BY) license (https://creativecommons.org/licenses/by/4.0/).

\section{Introduction}

Lung cancer is the most common form of other cancers, affecting smokers and nonsmokers at any age, causing high mortality worldwide [1]. Lung cancers are classified into two types' small cell lung cancer (SCLC) and non-small cell lung cancer (NSCLC), based upon the microscopic appearance of tumor cells [2]. SCLC comprises $10-15 \%$ of lung cancers due to strictly smoking, while NSLC accounts for $85 \%$ of lung cancer [3]. This epidemiological 
disease progression in India varied concerning age, gender, and smoking also. In India, approximately the risk of cancer development is approximate> 63,000/year [4]. Current therapy utilized for lung cancers is surgery, radiation therapy, immunotherapy, and chemotherapy. However, each therapy has its limitations and restrictions that hamper lung cancer treatment for long-term treatment [5]. Chemotherapy drugs profoundly affect cancer cells by acting as alkylating agents, anti-metabolites, antibiotics, topoisomerase inhibitors, mitotic inhibitors, and others [6-9]. At the current epoch, chemotherapy drugs like cisplatin, paclitaxel, docetaxel, methotrexate, bevacizumab, gefitinib, and cetuximab were clinically practiced for treating lung cancers but concerning the side effects and other associated disorders made it critically to be used for patients for a long period [10]. To overcome the side effects and other disorders, it is indeed to develop a novel payload biotic agent to be developed as a cancer drug for the upcoming future. Since from a historical perspective, naturally derived sources from plants and microbes have been utilized as agents in food industries, pharmacy, chemical industries, lead compounds, and environmental applications [11-13]. Cancer chemoprevention by using dietary or natural agents that can prevent the carcinogenic process is becoming limelight of research for decades. In this junction, plant-derived compounds such as flavonoids, phenols, terpenoids, carotenoids, lycopene, and other phytochemicals (coloring pigments) were well known proved in several chronic diseases such as cardiac problems, tumor, organs dysfunction, cataracts, immune-boosting, and bacterial/viral diseases [14].

Plant pigments (chlorophyll, carotenoid, quinone, melanin, anthocyanin, and betalain) play an essential role in photosynthesis, metabolism, and stress conditions [15, 16]. Apart from this, plant pigments also have some commercial values as food additives, coloring agents, textile, cosmetic, and particularly for therapeutic purposes [17]. Among plant pigments, betalain is a noteworthy pigment having a wide spectrum of commercial and therapeutic values. Beetroot belongs to the family of Caryophyllales, which contains red pigments (betacyanins) and yellow pigments (betaxanthins), which are altogether known as betalain. These betalains are water-soluble nitrogenous compounds present in the tuber of beetroots [18]. Commonly, the core structure of betalain contains the core betalamic acid, whereas the side chains R1 and $\mathrm{R} 2$ differentiate betacyanin and betaxanthin. The pigment present in red beetroot is betanin of betacyanin, which has various properties like antioxidant, anti-inflammatory, anticancer, diabetic, hypolipidemic, and hepatoprotective activities [19]. Moreover, betanin is approved and recommended as a food colorant by the Food and Drug Administration (FDA), the United States, and the European Union [20]. In the present study, we have assessed the betanin therapeutic properties in the A549 lung cancer cell line under in vitro conditions. Further intensely, we have simulated the interaction of key carcinogenic proteins with betanin through molecular docking studies to decipher the molecular mechanistic of betanin against A549 in the apoptosis process.

\section{Materials and Methods}

\subsection{Materials.}

Betanin (B0397) was purchased commercially from TCI chemicals (India) Private Limited, India. A549 cell line procured from National Centre for Cell Science (NCCS) Pune. All other analytical grade chemicals and reagents associated with the study were purchased from Sigma-Aldrich company private limited, India. 


\subsection{In vitro anticancer activity of betanin.}

2.2.1. Cell line and culture.

A549 cell line (Lung cancer cells) was procured from National Center for Cell Science (NCCS), Pune, India. The A549 cells were cultured in Dulbecco's Modified Eagle's medium (DMEM) (Gibco Co., Germany) supplemented with $10 \%$ fetal calf serum (FCS), antibiotics penicillin $(100 \mathrm{IU} / \mathrm{ml})$, and streptomycin $(100 \mu \mathrm{g} / \mathrm{ml})$, and incubated at $37{ }^{\circ} \mathrm{C}$ with $5 \% \mathrm{CO} 2$ incubator. After reaching $70 \%$ confluence, the cells were trypsinized into single cells and used for cell treatment.

\subsubsection{Cell treatment.}

A549 cells $\left(5 \times 10^{3}\right)$ were plated in 96 well plates and incubated for $6 \mathrm{~h}$. Different concentrations of betanin $(20-100 \mu \mathrm{M} / \mathrm{mL})$ were added and incubated at $37^{\circ} \mathrm{C}$ in a $\mathrm{CO}_{2}$ incubator for $24 \mathrm{~h}$. Control cells were treated with $2 \% \mathrm{DMSO}$ alone. As a drug-positive control, we used doxorubicin $(20-100 \mu \mathrm{M} / \mathrm{mL})$. All the experiments were performed in triplicate.

\subsubsection{Cytotoxicity assay.}

After treatment, the cells were assessed for cell viability in response to drug/chemicals. The medium was removed, and the A549 cells were incubated with $50 \mu \mathrm{L}$ of $0.5 \%$ MTT (3-[4, 5-dimethylthiazol-2-yl]-2, 5-diphenyltetrazolium bromide) reagent for $4 \mathrm{~h}$ at $37^{\circ} \mathrm{C}$ for the formation of formazan product. After incubation, $0.04 \mathrm{M} \mathrm{HCl} /$ isopropanol was added to the cells. The developed product was further dissolved in $100 \mu \mathrm{l}$ of dimethyl sulfoxide (DMSO), and the cells treated with $2 \%$ DMSO alone were used as blank in the experiments [21]. Further, the viability of the cells was determined by the spectrophotometric method using a scanning Multiwell spectrophotometer (Biorad, Model 680, Japan) by measuring the absorbance at 570 $\mathrm{nm}$. Percentage of cell viability was calculated by using the formula

$\%$ Cell Viability = OD Sample / OD Control x 100.

\subsubsection{Flow cytometer analysis.}

A549 lung cancer cells $2 \times 105$ cells were seeded in 6 well plates with and without betanin (IC50 $17 \mu \mathrm{M}$ ) and incubated at $37^{\circ} \mathrm{C}$ in a $\mathrm{CO}_{2}$ incubator for $24 \mathrm{~h}$, and cell cycle analysis was analyzed according to Pumiputavon et al. [22]. After treatment, the cells were washed and centrifuged at $1800 \mathrm{rpm}$ for $10 \mathrm{~min}$ and fixed with $70 \%$ ice-cold ethanol at $4{ }^{\circ} \mathrm{C}$ for $2 \mathrm{~h}$. After fixing, the A549 cells were washed twice with PBS and centrifuged at $1800 \mathrm{rpm}$ for $8 \mathrm{~min}$. The cell pellet was broken up by vortexing and resuspended in RNase A $(20 \mu \mathrm{g} / \mathrm{ml}), 250 \mu \mathrm{l}$ PBS containing PI $(20 \mu \mathrm{g} / \mathrm{ml})$, and Triton X-100 (0.1\%), and incubated for $30 \mathrm{~min}$ in the dark. The stained cell sample was analyzed by flow cytometry (BD FACSCalibur, BD Biosciences, USA), and cell cycle distribution was calculated using the flow jow software.

\subsection{In silico studies of betanin with cell signaling proteins.}

The docking studies were done using the molecular docking tool, glide Schrodinger for the selected proteins (Human Topo IIa ATPase / AMP-PNP, Human DNA topoisomerase I, Antiapoptotic protein Bcl-2, CDK-6, and Caspase 3) against betanin. These proteins were 
downloaded from Protein Data Bank (PDB) with the accession numbers 1ZXM, 1T8I, 2O2F, $1 \mathrm{XO} 2$, and $2 \mathrm{~J} 30$.

Glide is one of the best precise docking tools existing for ligand-protein binding studies. Using the docking software, Schrödinger Maestro Version 10.3.014, selected protein structures were retrieved and prepared for the study [23]. Initially, the side chains missing within the proteins were assigned by Prime (Schrodinger). Further, water molecules, ions, and co-factors were deleted, hydrogen atoms were added, and other formal charges along with bond orders were assigned to the protein structure.

Receptor grids were calculated for prepared proteins such that ligand will bind within the predicted active site during docking. In Glide, grids were generated keeping the default parameters of van der Waals scaling factor 1.00 and charge cut-off 0.25 subjected to OPLS 2001 force field. A cubic box of specific dimensions centered on the centroid of the active site residues (predicted by site map) was generated for each receptor.

The ligand betanin was sketched in ChemDraw and saved in MOL format. Consequently, the ligand was prepared using LigPrep (Schrodinger) by adjusting the torsions of the ligands and assigning them proper protonation positions. In Glide (Schrodinger), 32 stereochemical structures were generated per ligand with possible states at target $\mathrm{pH} 7.0 \pm 2.0$ using ionizer, tautomerized, desalted, and optimized by producing low energy 3D structure for the ligand under the OPLS 2005 force field while retaining the specified chiralities of the input Maestro file. Ligand docking SP flexible ligand docking was carried out in Glide of Schrödinger- MaestroVersion 10.3.014 inside which consequences were useful to non-cis/trans amide bonds. Van der Waals scaling factor and partial charge cut-off were particular to be 0.80 and 0.15 , correspondingly for ligand atoms. Final scoring was achieved on energy-minimized poses and exhibited as a Glide score. The best-docked pose with the lowest Glide score value was recorded for each ligand.

\section{Results and Discussion}

\subsection{Cytotoxic effects of betanin.}

In vitro cytotoxicity assays were performed on betanin-treated A549 lung cancer cell lines. MTT assay was inferred to test betanin's cytotoxic efficacy against lung cancer cell lines, as shown in Figures 1 and 2.

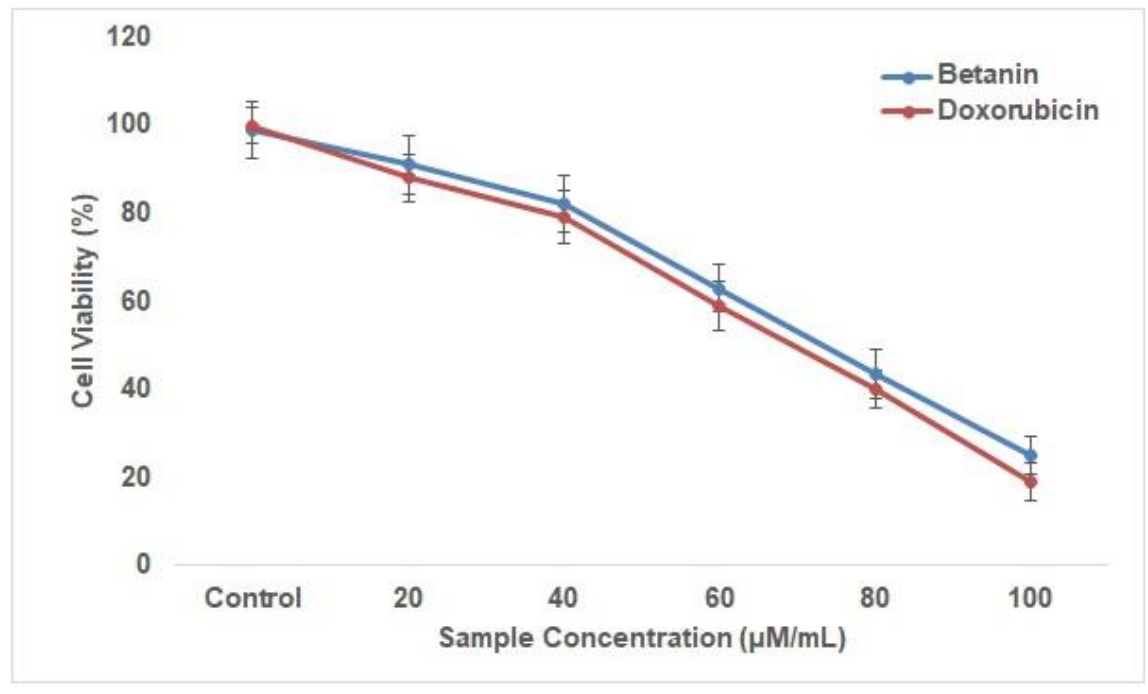

Figure 1. Cytotoxic effect of betanin on A549 lung cancer cells. 
The cytotoxic effects of betanin trigger the activity in a dose-dependent manner in 24 h $(20-100 \mu \mathrm{M} / \mathrm{mL})$. Cytotoxicity effects increase in a concentration-dependent manner. The IC $_{50}$ for cytotoxicity with betanin was $73.5 \mu \mathrm{M} / \mathrm{mL}$. The cytotoxic potential of betanin demonstrates as a promising anticancer agent (Figure 1). The effect of betanin on A549 lung cancer cells was observed through microscopy (Figure 2a-f). The microscopic images depict that bioactive phytocompound betanin triggers apoptosis, leading to cell death, resulting in bubbling, collapse, and leakage of the internal organelle (Figure 2a-f).
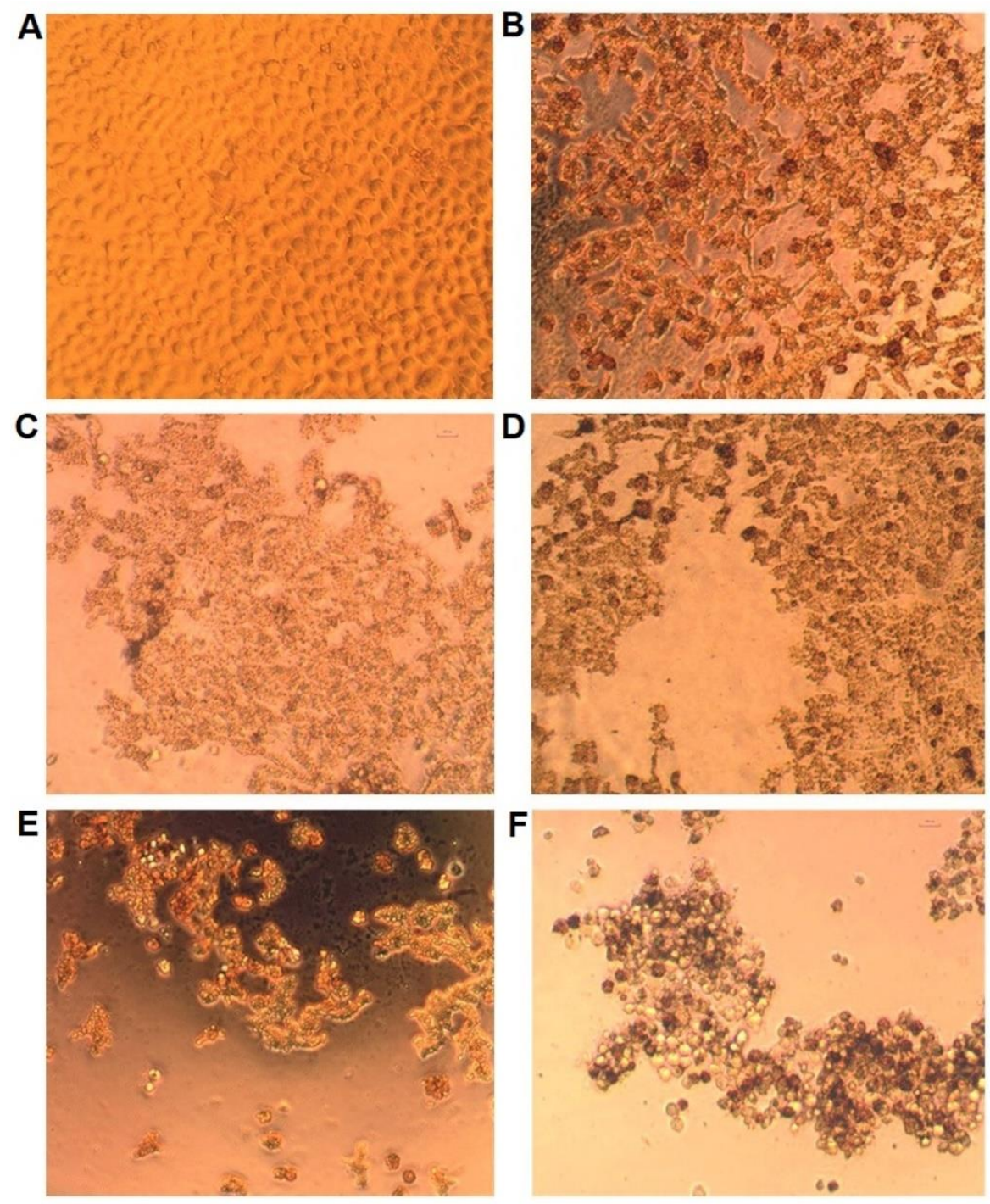

Figure 2a-f. Anti-cancer effect of with and without betanin on A549 lung cancer cell line. (A) Control cells (A549 cells treated with DMSO alone); (B) Betanin $(20 \mu \mathrm{M} / \mathrm{mL})$ treated A549 cells; (C) Betanin $(40 \mu \mathrm{M} / \mathrm{mL})$ treated A549 cells; (D) Betanin $(60 \mu \mathrm{M} / \mathrm{mL})$ treated A549 cells; (E) Betanin $(80 \mu \mathrm{M} / \mathrm{mL})$ treated A549 cells;

(F) Betanin $(20 \mu \mathrm{M} / \mathrm{mL})$ treated A549 cells.

Our previous studies have shown the anticancer property against A549 lung cancer cell lines of aqueous extract of Beta vulgaris copper oxide nanoparticles [24]. This earlier study was interested in deciphering that betanin is the predominant compound, and subsequently we have selected betanin to assess its specific in vitro and in silico analysis. We concur with our results that betanin executed enhanced cytotoxicity effects with a concentration-dependent manner on the A549 lung cancer cell line (IC50 $73 \mu \mathrm{M}$ ), revealing that betanin possesses antiproliferative activity. Nowacki et al. [23] experimental analysis on partial extracted and purified betanin/isobetanin (Bet/Isobet) from Beta vulgaris against cancer cells such as 
B16F10, MCF-7, MDA-MB-231, HT-29, and normal cells (HUVEC, MRC-5) cells demonstrated that Bet/Isobet exhibited enhanced activity in cancer cells (B16F10, MCF-7 -

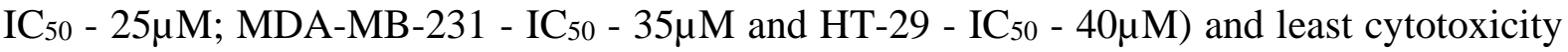
was noticed in normal cells. Betanin induced cytotoxicity through apoptosis with increased gene expression of apoptotic proteins (Bad, TRAILR4, FAS, phosphorylated p53) and loss of mitochondrial membrane potential [25] in cancer cells.

\subsection{Cell-cycle effects of betanin.}

Cell cycle analysis was performed to observe whether the bioactive betanin caused the apoptotic cell death on inhibitory effect on the cell cycle process. Although betanin showed a maximum potent effect on A549 lung cancer cell lines and was chosen for the cell cycle analysis to detect its anticancer activity (Figure 3a and b). A549 cells were treated with and without betanin ( $\mathrm{IC}_{50} 73.5 \mu \mathrm{M} / \mathrm{mL}$ ) for $24 \mathrm{~h}$, stained with propidium iodide, and successively analyzed the cell cycle by flow cytometry. A549 cells report revealed an increase in the DNA fragmentation as reflected by the increase in the percentages of cells in the sub G1 phase compared to the control cells. The cell cycle analysis showed a remarkable decrease in the percentage of cells in the G1 phase (14.2\%) and a moderate decrease in the S phase $(30.5 \%)$, while an exponential increase was noted in the G2/M phase (49.6\%) (Fig. 3b) compared with control (Figure 3a and $b$ ).
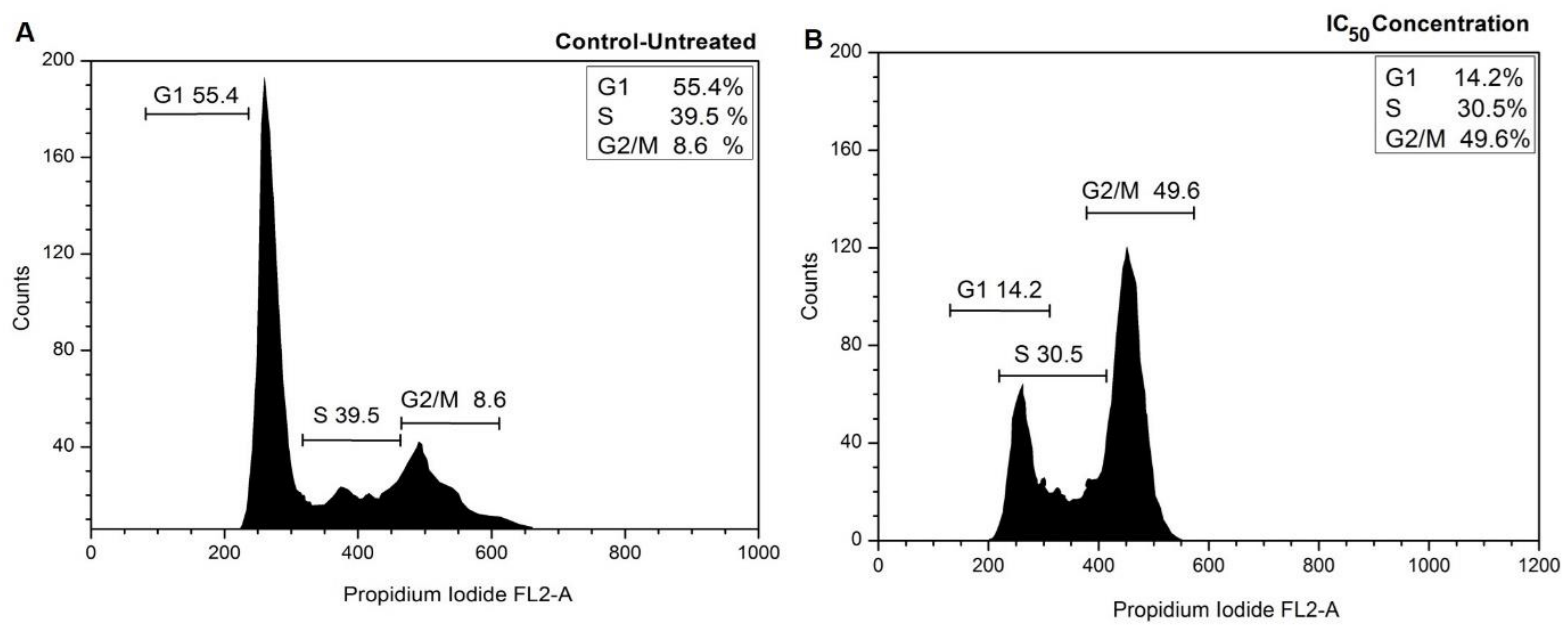

Figure 3a and b. Cell cycle analysis of A549 lung cancer cells treated with and without betanin histograms and gating strategy shows the patterns of cells stained with PI by FACS. (A) A549 lung cancer cells treated with

DMSO alone were used as the control. (B) A549 lung cancer cells treated betanin $\left(\mathrm{IC}_{50} 17 \mu \mathrm{M} / \mathrm{mL}\right)$.

Our results of betanin on cell cycle analysis showed a remarkable decrease in the percentage of cells in the G1 phase (14.2\%) and a moderate decrease in the S phase $(30.5 \%)$, while an exponential increase was noted in the $\mathrm{G} 2 / \mathrm{M}$ phase (49.6\%). This phenomenon of the change in the percentage of cells from the G1- S- G2/M phase may be attributed to the downregulation of cyclin A2 and B1 levels [26-28].

\subsection{In Silico analysis of betanin.}

The grid box was constructed by molecular docking with adequate size to permit the probe into the binding site with targeted proteins. The 3D structural analysis for targeted cancer signaling proteins through protein data bank (PDB) entry (1ZXM, 1T8I, 2O2F, 1XO2, and 2J30) was analyzed by in silico analysis. We elucidate and calculate different types of 
interactions between ligand-receptor interactions such as hydrogen bonding, pi-pi interactions, van der Waal interactions, steric interactions, and docking score (Table 1). Based on the Gscore parameter, the binding affinity of the ligand towards receptors was determined. The higher negative value of the glide score indicates a more excellent binding relationship of the ligand with the receptor.

Table 1. Molecular docking studies of betanin with cancer proteins and their predicted scores.

\begin{tabular}{|c|c|c|c|c|c|c|}
\hline Protein & $\begin{array}{l}\text { PDB } \\
\text { ID }\end{array}$ & Binding sites & Distance & Interactions & $\begin{array}{c}\text { Docking } \\
\text { score }\end{array}$ & $\begin{array}{c}\text { Glide } \\
\text { emodel }\end{array}$ \\
\hline $\begin{array}{l}\text { Human DNA } \\
\text { topoisomerase I }\end{array}$ & 1T8I & $\begin{array}{l}\text { ARG362 } \\
\text { GLY363 } \\
\text { ARG364 } \\
\text { LYS374 } \\
\text { LYS425 } \\
\text { THR501 } \\
\text { ASP533 }\end{array}$ & $\begin{array}{l}1.93 \\
2.45 \\
4.99 \\
5.31 \\
3.36 \\
2.10 \\
1.99 \\
1.70 \\
\end{array}$ & $\begin{array}{c}\mathrm{H} \text { bond } \\
\mathrm{H} \text { bond } \\
\text { Salt bridge } \\
\text { Pi-Pi stacking } \\
\text { Salt bridge } \\
\mathrm{H} \text { bond } \\
\mathrm{H} \text { bond } \\
\mathrm{H} \text { bond }\end{array}$ & -8.148 & -98.821 \\
\hline $\begin{array}{c}\text { Human Topo IIa } \\
\text { ATPase/AMP-PNP }\end{array}$ & $1 \mathrm{ZXM}$ & $\begin{array}{l}\text { GLU66 } \\
\text { TYR244 } \\
\text { ASN258 } \\
\text { LYS261 } \\
\end{array}$ & $\begin{array}{l}1.99 \\
4.94 \\
1.96 \\
1.73 \\
1.74 \\
\end{array}$ & $\begin{array}{c}\mathrm{H} \text { bond } \\
\text { Salt bridge } \\
\mathrm{H} \text { bond } \\
\mathrm{H} \text { bond } \\
\mathrm{H} \text { bond }\end{array}$ & -5.728 & -55.357 \\
\hline CDk-6 & $1 \mathrm{XO} 2$ & $\begin{array}{l}\text { TRP41 } \\
\text { PRO74 } \\
\text { SER78 } \\
\text { ASP81 } \\
\text { LYS86 } \\
\\
\text { VAL150 } \\
\text { ALA152 } \\
\text { LYS144 } \\
\end{array}$ & $\begin{array}{l}2.71 \\
2.10 \\
2.67 \\
2.37 \\
4.93 \\
1.86 \\
1.97 \\
2.59 \\
2.61 \\
2.76 \\
4.07 \\
\end{array}$ & $\begin{array}{c}\mathrm{H} \text { bond } \\
\mathrm{H} \text { bond } \\
\mathrm{H} \text { bond } \\
\mathrm{H} \text { bond } \\
\text { Salt bridge } \\
\mathrm{H} \text { bond } \\
\mathrm{H} \text { bond } \\
\mathrm{H} \text { bond } \\
\mathrm{H} \text { bond } \\
\mathrm{H} \text { bond } \\
\text { Salt }\end{array}$ & -8.132 & -81.243 \\
\hline Bcl-2 & $2 \mathrm{O} 2 \mathrm{~F}$ & $\begin{array}{l}\text { TYR105 } \\
\text { ASP108 } \\
\text { ARG143 }\end{array}$ & $\begin{array}{l}1.75 \\
4.90 \\
1.83 \\
1.85 \\
2.00 \\
1.77\end{array}$ & $\begin{array}{l}\mathrm{H} \text { bond } \\
\mathrm{Pi} \text { cation } \\
\mathrm{H} \text { bond } \\
\mathrm{H} \text { bond } \\
\mathrm{H} \text { bond } \\
\mathrm{H} \text { bond }\end{array}$ & -4.522 & -45.002 \\
\hline Caspase 3 & $2 \mathrm{~J} 30$ & $\begin{array}{l}\text { TYR41 } \\
\text { HIE277 } \\
\text { LYS82 }\end{array}$ & $\begin{array}{l}2.56 \\
1.85 \\
1.93 \\
1.87\end{array}$ & $\begin{array}{l}\mathrm{H} \text { bond } \\
\mathrm{H} \text { bond } \\
\mathrm{H} \text { bond } \\
\mathrm{H} \text { bond }\end{array}$ & -6.108 & -60.470 \\
\hline
\end{tabular}

Molecular docking of betanin with topoisomerase I exhibited enhanced interaction compared to topoisomerase II, and their docking score was $-8.148 \mathrm{kcal} / \mathrm{mol}$ (Figure 4a and b). In the binding pattern, seven residues have resided in the binding site of the topoisomerase I ligand that possesses H-bond, salt bridge, and Pi-Pi interactions with the amino acids ARG362, GLY363, ARG364, LYS374, LYS425, THR501, and ASP533 (Figure 4a). Similarly, docking of betanin with topoisomerase II revealed better interaction, and their docking score was -5.728 $\mathrm{kcal} / \mathrm{mol}$. Four residues reside in the binding site of topoisomerase II with a ligand that possesses only H-bond interactions with the amino acid residues GLU66, TYR244, ASN258, and LYS261 (Figure 4b).

CDK-6 exhibited superior interaction with betanin, and their docking score was -8.132 $\mathrm{kcal} / \mathrm{mol}$ (Figure $4 \mathrm{c}$ ). The highest numbers of residues were residing in the binding site of CDK-6 with the formation of H-bond interactions with amino acid TRP41, PRO74, SER78, ASP81, LYS86, VAL150, ALA152, and LYS144. 
Molecular docking of betanin with BcL-2 protein revealed six best interactions by residues of the ligand that possess H-bond and Pi-Pi cation interactions with TYR105, ASP108 ARG143 amino acid. Upon all amino acid interactions, the ASP108 showed an intensively binding score with betanin of $-4.5 \mathrm{kcal} / \mathrm{mol}$ (Figure $4 \mathrm{~d}$ ). Similarly, docking of betanin with Caspase- 3 exhibited enhanced interaction and their score of $-6.108 \mathrm{kcal} / \mathrm{mol}$ (Figure $4 \mathrm{e}$ ). Three residues were residing in the binding site of Caspase-3 with a ligand that possesses only $\mathrm{H}$ bond interactions with the amino acid residues TYR41, HIE277, and LYS82.
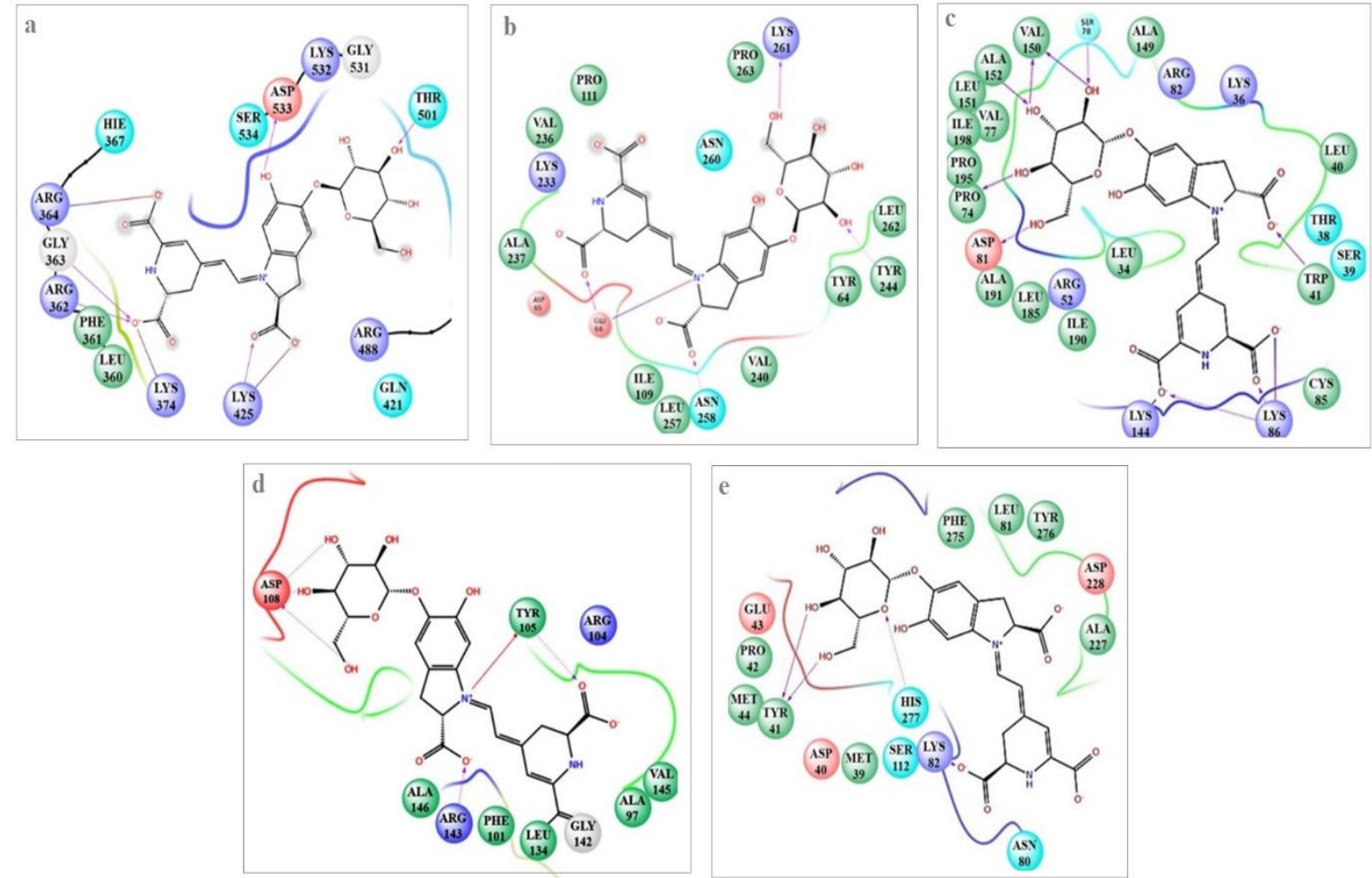

Figure 4a-e. 2D Molecular docking of ligand-receptor interaction diagrams of representative betanin against cancer signaling proteins. (a) Topoisomerase I; (b) a) Topoisomerase IIa; (c) CDK-6; (d) BcL-2; (e) Caspase-3.

In-silico analysis is pioneering scientific predictions of the ligand-receptor interaction to develop and validate new novel drugs. We have deciphered the interaction dynamics of betanin against cell signaling proteins such as topoisomerase I and II (DNA replication), CDK6 (cell cycle progression), BcL-2, and caspase-3 (apoptosis) by molecular docking (Schrodinger docking tool). Interestingly, betanin and doxorubicin chemical structures closely resemble each other, i.e., the planar configuration of an aromatic chromophore attached to a six-membered sugar molecule [29, 30]. The molecular mechanistic action of doxorubicin is exerted by intercalation of DNA bases and by inhibition of DNA topoisomerases I and II activities. We are inconsistent with the report of Radaeva et al. [31] docked proceraside A from Calotropis procera with topoisomerase I and II with a docking score of $-11.69 \mathrm{kcal} / \mathrm{mol}$ and $11.09 \mathrm{kcal} / \mathrm{mol}$. Likewise, we concur with Rosdi et al. [32] docked 15 bioactive compounds from Annona muricata against BcL-2. Among 15 bioactive compounds, anonaine (-8.11 $\mathrm{kcal} / \mathrm{mol})$, coreximine $(-7.13 \mathrm{kcal} / \mathrm{mol})$, synephrine $(-5.09 \mathrm{kcal} / \mathrm{mol})$, obatoclax $(-7.01$ $\mathrm{kcal} / \mathrm{mol}$ ) demonstrated better docking affinity with BcL-2. Our docking results were significant compared with reports of Jayameena et al. [33], which revealed rutin compound against caspase- 3 with a docking score of $-2.95 \mathrm{kcal} / \mathrm{mol}$. Thus, we corroborate with earlier reports that 15 active compounds from Himalayan plant and molecular docking with CDK-6 
signaling proteins, 8 compounds have a better affinity with CDK-6, and docking score ranges from $(-6.00$ to $-11.09 \mathrm{kcal} / \mathrm{moL})[34,35]$.

Overall, the docking pattern of betanin with cancer signaling proteins has high significance with a good docking score value. In particular, proteins-ligand interaction, topoisomerase I and II. CDK-6 docking kinetics were superior while compared with others cancer signaling proteins. Herein betanin is reported with a good affinity with cancer signaling proteins and might be designed for novel cancer drug development. Moreover, betanin is a safe coloring dye that possesses various bioactivities and is chemo-preventive and imparts without any toxic side effects [19]. Overall, we proposed that molecular docking of betanin on topoisomerase II $\alpha$ direct blocking alters $\mathrm{H} 3$ and $\mathrm{H} 4$ function.

Furthermore, it induces the apoptotic process and inhibits cell proliferation. Betanin simultaneously blocks CDK-6 signals resulting in the inhibition of cell cycle progression and cell proliferation. Betanin directly or indirectly induces apoptosis by blocking suppressing Bcl2 leading to membrane permeability and loss of mitochondrial membrane, and release of cytochrome c. Bax and cytochrome c enhance the upregulation of caspase 9 and caspase 3. DNA fragmentation leads to the induction of mitochondria-mediated extrinsic pathways of apoptosis. In another way, betanin activates caspase-3-mediated apoptosis; moreover, activation of caspase-3 results in DNA fragmentation and apoptosis (Figure 5).

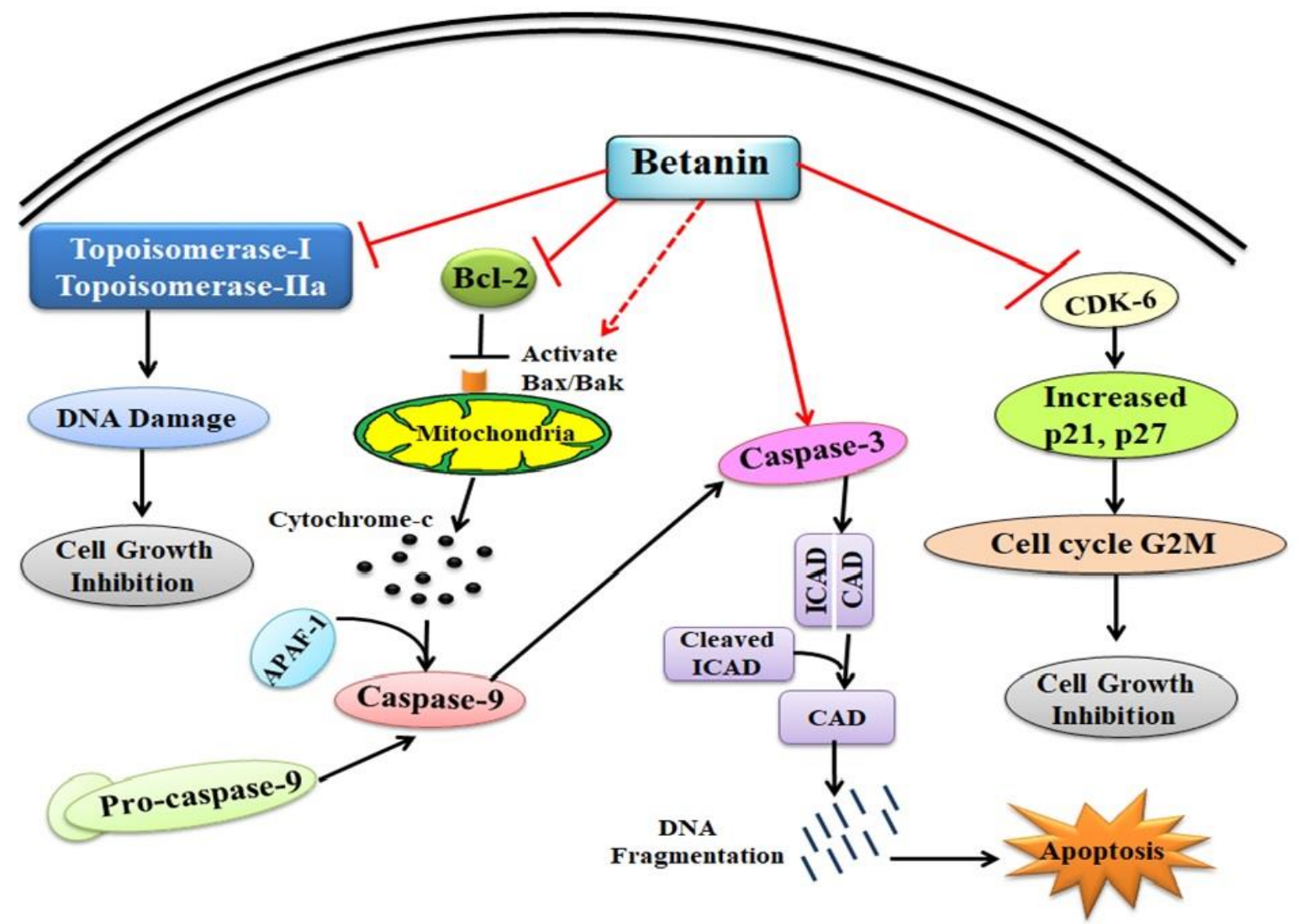

Figure 5. Schematic representation of targeting and apoptotic events modulated by betanin in malignant cells.

\section{Conclusions}

The present study portrayed the molecular mechanistic activity of betanin in lung cancer cells (A549). Cytotoxic effects of betanin effectively cause increases cell death in a dose-dependent manner on A549 cells by arresting the cell cycle at G1 phase revealed by flow cytometry analysis. The molecular docking analysis revealed that betanin has effectively 
interacted with the proteins with high affinity with cancer signaling proteins with BcL-2, caspase-3, CDK-6, topoisomerase I and II proteins, which showed imperative docking scores. Thus the preliminary intrinsic study concludes that betanin can be exploited as a new paradigm in novel drug development. Furthermore, future investigations need to focus on in vivo analysis, confirming its toxicity analysis and molecular mechanisms underlying the cytotoxic and anticancer properties.

\section{Funding}

This work was financially supported by the Department of Science and Technology, Government of India, under the scheme of DST-FIST (SR/FST/LS-1/2018/187 Dt.26.12.2018).

\section{Acknowledgments}

This research has no acknowledgments.

\section{Conflicts of Interest}

We author have no conflict of interest regarding the manuscript preparations, submission, and publication.

\section{References}

1. Smolle, E.; Pichler, M. Non-Smoking-Associated Lung Cancer: A distinct Entity in Terms of Tumor Biology, Patient Characteristics and Impact of Hereditary Cancer Predisposition. Cancers 2019, 11, 204, https://dx.doi.org/10.3390/cancers11020204.

2. Zappa, C.; Mousa, S.A. Non-small cell lung cancer: current treatment and future advances. Translational Lung Cancer Research 2016, 5, 288-300, https://dx.doi.org/10.21037/tlcr.2016.06.07.

3. Yuan, M.; Huang, L.L.; Chen, J.H.; Wu, J.; Xu, Q. The emerging treatment landscape of targeted therapy in non-small-cell lung cancer. Signal Transduction and Targeted Therapy 2019, 4, 1-4, https://dx.doi.org/10.1038/s41392-019-0099-9.

4. Noronha, V.; Pinninti, R.; Patil, V.M.; Joshi, A.; Prabhash, K. Lung cancer in the Indian subcontinent. South Asian Journal of Cancer 2016, 5, 95, https://dx.doi.org/10.4103/2278-330X.187571.

5. Wirsdörfer, F.; De Leve, S.; Jendrossek, V. Combining Radiotherapy, and Immunotherapy in Lung Cancer: Can We Expect Limitations Due to Altered Normal Tissue Toxicity? International Journal of Molecular Sciences 2019, 20, 24, https://doi.org/10.3390/ijms20010024.

6. Zheng, J.; Zhou, Y.; Li, Y.; Xu, D.P.; Li, S.; Li, H.B. Spices for prevention and treatment of cancers. Nutrients 2016, 8, 495, https://doi.org/10.3390/nu8080495.

7. Xu, D.P.; Li Y.; Meng, X.; Zhou, T.; Zhou, Y.; Zheng, J.; Zhang, J.J.; Li, H.B. Natural antioxidants in foods and medicinal plants: Extraction, assessment and resources. International Journal of Molecular Sciences 2017, 18, 96, https://doi.org/10.3390/ijms18010096.

8. Cuzick, J. Preventive therapy for cancer. The Lancet Oncology 2017, 18, e472-e482, https://doi.org/10.1016/S1470-2045(17)30536-3

9. Cao, S.Y.; Li, Y.; Meng, X.; Zhao, C.N.; Li, S.; Gan, R.Y.; Li, H.B. Dietary natural products and lung cancer: Effects and mechanisms of action. Journal of Functional Foods 2019, 52, 316-331, https://doi.org/10.1016/j.jff.2018.11.004.

10. Sharma, P.; Mehta, M.; Dhanjal, D.S.; Kaur, S.; Gupta, G.; Singh, H.; Thangavelu, L.; Rajeshkumar, S.; Tambuwala, M.; Bakshi, H.A.; Chellappan, D.K. Emerging trends in the novel drug delivery approaches for the treatment of lung cancer. Chemico-Biological Interactions 2019, 309, 108720, https://doi.org/10.1016/j.cbi.2019.06.033.

11. Atanasov, A.G.; Waltenberger, B.; Pferschy-Wenzig, E.M.; Linder, T.; Wawrosch, C.; Uhrin, P.; Temml, V.; Wang, L.; Schwaiger, S.; Heiss, E.H.; Rollinger, J.M. Discovery and resupply of pharmacologically active 
plant-derived natural products: A review. Biotechnology Advances 2015, 33, 1582-1614, https://doi.org/10.1016/j.biotechadv.2015.08.001.

12. Sen, S.; Chakraborty, R. Revival, modernization and integration of Indian traditional herbal medicine in clinical practice: Importance, challenges and future. Journal of Traditional and Complementary Medicine 2017, 7, 234-244, https://doi.org/10.1016/j.jtcme.2016.05.006.

13. Newman, D.J.; Cragg, G,M. Natural products as sources of new drugs over the nearly four decades from 01/1981 to 09/2019. Journal of Natural Product 2020, 83, 770-803, https://doi.org/10.1021/acs.jnatprod.9b01285.

14. John, T.; Samuel, B.; Abolaji, O.; Folashade, O.; Oyetooke, A.; Oluwatosin, F. Functional foods and bioactive compounds: Roles in the prevention, treatment and management of neurodegenerative diseases. GSC Biological and Pharmaceutical Sciences 2020, 11, 297-313, https://doi.org/10.30574/gscbps.2020.11.2.0143.

15. Upadhyay, R.K. Plant pigments as dietary anticancer agents. International Journal of Green Pharmacy 2018, 12, S93, http://dx.doi.org/10.22377/ijgp.v12i01.1604.

16. Ahmadi, H.; Nayeri, Z.; Minuchehr, Z.; Sabouni, F.; Mohammadi, M. Betanin purification from red beetroots and evaluation of its antioxidant and anti-inflammatory activity on LPS-activated microglial cells. PloS One 2020, 15, e0233088, https://doi.org/10.1371/journal.pone.0233088.

17. Rodriguez-Amaya, D.B. Update on natural food pigments-A mini-review on carotenoids, anthocyanins, and betalains. Food Research International 2019, 124, 200-205, https://doi.org/10.1016/j.foodres.2018.05.028.

18. Polturak, G.; Aharoni, A. "La Vie En Rose": biosynthesis, sources, and applications of betalain pigments. Molecular Plant 2018, 11, 7-22, https://doi.org/10.1016/j.molp.2017.10.008.

19. Lechner, J.F.; Stoner, G.D. Red beetroot and betalains as cancer chemopreventative agents. Molecules 2019 , 24, 1602, https://doi.org/10.3390/molecules24081602.

20. da Silva, D.V.; dos Santos Baião, D.; de Oliveira Silva, F.; Alves, G.; Perrone, D.; Del Aguila, E.M.; Paschoalin, V.M. Betanin, a Natural Food Additive: Stability, Bioavailability, Antioxidant and Preservative Ability Assessments. Molecules 2019, 24, 458, https://dx.doi.org/10.3390/molecules24030458.

21. Vajrabhaya, L.O.; Korsuwannawong, S. Cytotoxicity evaluation of a Thai herb using tetrazolium (MTT) and sulforhodamine B (SRB) assays. Journal of Analytical Science and Technology 2018, 9, 1-6, https://doi.org/10.1186/s40543-018-0146-0.

22. Pumiputavon, K.; Chaowasku, T.; Saenjum, C.; Osathanunkul, M.; Wungsintaweekul, B.; Chawansuntati, K.; Wipasa, J.; Lithanatudom, P. Cell cycle arrest and apoptosis induction by methanolic leaves extracts of four Annonaceae plants. BMC Complementary and Alternative Medicine 2017, 17, https://doi.org/10.1186/s12906-017-1811-3.

23. Jiménez-Luna, J.; Grisoni, F.; Weskamp, N.; Schneider, G. Artificial intelligence in drug discovery: Recent advances and future perspectives. Expert Opinion on Drug Discovery 2021, 11, https://doi.org/10.1080/17460441.2021.1909567.

24. Chandrasekaran, R.; Yadav, S.A.; Sivaperumal, S. Phytosynthesis and characterization of copper oxide nanoparticles using the aqueous extract of beta vulgaris $\mathrm{L}$ and evaluation of their antibacterial and anticancer activities. Journal of Cluster Science 2020, 31, 221-230, https://doi.org/10.1016/j.jphotobiol.2017.05.001.

25. Hadipour, E.; Taleghani, A.; Tayarani-Najaran, N.; Tayarani-Najaran, Z. Biological effects of red beetroot and betalains: A review. Phytotherapy Research 2020, 34, 1847-1867, https://doi.org/10.1002/ptr.6653.

26. Wu, X.; Li, M.; Xiao, Z.; Daglia, M.; Dragan, S.; Delmas, D.; Vong, C.T.; Wang, Y.; Zhao, Y.; Shen, J.; Nabavi, S.M. Dietary polyphenols for managing cancers: What have we ignored? Trends in Food Science \& Technology 2020, 101, 150-164, https://doi.org/10.1016/j.tifs.2020.05.017.

27. Kalhori, M.R.; Khodayari, H.; Khodayari, S.; Vesovic, M.; Jackson, G.; Farzaei, M.H.; Bishayee, A. Regulation of Long Non-Coding RNAs by Plant Secondary Metabolites: A Novel Anticancer Therapeutic Approach. Cancers 2021, 13, 1274, https://doi.org/10.3390/cancers13061274.

28. Khan, H.; Ullah, H.; Castilho, P.C.; Gomila, A.S.; D'Onofrio, G.; Filosa, R.; Wang, F.; Nabavi, S.M.; Daglia, M.; Silva, A.S.; Rengasamy, K.R. Targeting NF- $\kappa$ B signaling pathway in cancer by dietary polyphenols. Critical Reviews in Food. Science and Nutrition 2020, 60, 2790-2800, https://doi.org/10.1080/10408398.2019.1661827.

29. Venugopal, K.; Ahmad, H.; Manikandan, E.; Arul, K.T.; Kavitha, K.; Moodley, M.K.; Rajagopal, K.; Balabhaskar, R.; Bhaskar, M. The impact of anticancer activity upon Beta vulgaris extract mediated biosynthesized silver nanoparticles (ag-NPs) against human breast (MCF-7), lung (A549) and pharynx (Hep2) cancer cell lines. Journal of Photochemistry and Photobiology B: Biology 2017, 173, 99-107, https://doi.org/10.1016/j.jphotobiol.2017.05.031. 
30. Albasher, G.; Almeer, R.; Al-Otibi, F.O.; Al-Kubaisi, N.; Mahmoud, A.M. Ameliorative effect of Beta vulgaris root extract on chlorpyrifos-induced oxidative stress, inflammation and liver injury in rats. Biomolecules 2019, 9, 261, https://doi.org/10.3390/biom9070261.

31. Radaeva, M.; Dong, X.; Cherkasov, A. The Use of Methods of Computer-Aided Drug Discovery in the Development of Topoisomerase II Inhibitors: Applications and Future Directions. Journal of Chemical Information and Modeling 2020, 60, 3703-3721, https://doi.org/10.1021/acs.jcim.0c00325.

32. Rosdi, M.N.; Arif, S.M.; Bakar, M.H.; Razali, S.A.; Zulkifli, R.M.; Ya'akob, H. Molecular docking studies of bioactive compounds from Annona muricata Linn as potential inhibitors for Bcl-2, Bcl-w and Mcl-1 antiapoptotic proteins. Apoptosis 2018, 23, 27-40, https://doi.org/10.1007/s10495-017-1434-7.

33. Jayameena, P.; Sivakumari, K.; Ashok, K.; Rajesh, S. In Silico Molecular Docking Studies of Rutin Compound against Apoptotic Proteins (Tumor Necrosis Factor, Caspase-3, NF-Kappa-B, P53, Collagenase, Nitric Oxide Synthase and Cytochrome C). Journal of Cancer Research and Treatment 2018, 6, 28-33, https://doi.org/10.12691/jcrt-6-2-1.

34. Ali, M.A. Molecular docking and molecular dynamics simulation of anticancer active ligand ' $3,5,7,3$ ', 5'pentahydroxy-flavanonol-3-O- $\alpha$-L-rhamnopyranoside'from Bauhinia strychnifolia Craib to the cyclindependent protein kinase. Journal of King Saud University-Science 2020, 32, 891-895, https://doi.org/10.1016/j.jksus.2019.05.004.

35. Gurung, A,B.; Bhattacharjee,A.; Ali, M.A. Exploring the physicochemical profile and the binding patterns of selected novel anticancer Himalayan plant derived active compounds with macromolecular targets. Informatics in Medicine Unlocked 2016, 5, 1-14, https://doi.org/10.1016/j.imu.2016.09.004. 